University of Nebraska - Lincoln

DigitalCommons@University of Nebraska - Lincoln

2005

\title{
A Curious Pellet From a Great Horned Owl (Bubo Virginianus)
}

Neal Woodman

USGS Patuxent Wildlife Research Center, woodmann@si.edu

Carla J. Dove

National Museum of Natural History, dovec@si.edu

Suzanne C. Peurach

USGS Patuxent Wildlife Research Center, Suzanne_Peurach@usgs.gov

Follow this and additional works at: https://digitalcommons.unl.edu/usgsstaffpub

Woodman, Neal; Dove, Carla J.; and Peurach, Suzanne C., "A Curious Pellet From a Great Horned Owl (Bubo Virginianus)" (2005). USGS Staff -- Published Research. 619.

https://digitalcommons.unl.edu/usgsstaffpub/619

This Article is brought to you for free and open access by the US Geological Survey at DigitalCommons@University of Nebraska - Lincoln. It has been accepted for inclusion in USGS Staff -- Published Research by an authorized administrator of DigitalCommons@University of Nebraska - Lincoln. 


\title{
A Curious Pellet From a Great Horned Owl (Bubo Virginianus)
}

\author{
Neal Woodman ${ }^{1 *}$, Carla J. Dove ${ }^{2}$, and Suzanne C. Peurach ${ }^{1}$
}

\begin{abstract}
One of the traditional methods of determining the dietary preferences of owls relies upon the identification of bony remains of prey contained in regurgitated pellets. Discovery of a pellet containing a large, complete primary feather from an adult, male Ring-necked Pheasant (Phasianus colchicus) prompted us to examine in detail a small sample of pellets from a Great Horned Owl (Bubo virginianus). Our analyses of feather and hair remains in these pellets documented the presence of three species of birds and two species of mammals, whereas bones in the pellets represented only mammals. This finding indicates an important bias that challenges the reliability of owl pellet studies making use of only osteological remains.
\end{abstract}

Six egested pellets from a Great Horned Owl, Bubo virginianus (Gmelin, 1788), were collected on 13 April 2003 along the northeast side of Blue Marsh Lake, ca. 11 mi north of Reading, Penn Township, Berks County, PA. The pellets were scattered beneath a large black walnut tree (Juglans nigra Linné, 1753) along the edge of a windbreak of trees bordering a grassy, overgrown field just north of Old Church Road and west of Route 183. They are all believed to be from a single individual because of their proximity and their similar size and shape. One of these pellets (catalogue USNM 601957) is unusual because it contains a large (> $190 \mathrm{~mm}$ long when extended), complete primary (P-9) feather (Fig. 1) from the right wing of an adult, male Ring-necked Pheasant (Phasianus colchicus Linné, 1758). The pellet also contains large fragments of other feathers, although none with shaft diameters as great as the complete P-9. Other than these feathers, the pellet consists primarily of compacted hairs. No bones are apparent on the surface, nor were any revealed by digital x-ray. Our review of the literature on raptor pellets and our discussions with colleagues revealed no previous instances of an item as large as the primary feather being discovered incorporated into the body of a regurgitated pellet.

The visual impact of USNM 601957, and the fact that no bones of pheasant were present, encouraged us to examine all of the pellets more closely, paying particular attention to the correspondence among incorporated feathers, hairs, and osteological remains. We identified feathers by direct comparison with museum specimens and by use of microscopic

${ }^{1}$ USGS Patuxent Wildlife Research Center, MRC-111, National Museum of Natural History, Washington, DC 20013. ${ }^{2}$ Division of Birds, Department of Zoology, MRC116, National Museum of Natural History, Washington, DC 20013. *Corresponding author-woodman.neal@nmnh.si.edu. 
characteristics in the plumulaceous (downy) barbs (Sabo and Laybourne 1994). Hair samples were identified to family by comparison with whole museum specimens and with microscope reference slides (Day 1966). Bones and teeth were identified by comparison with museum specimens.

We identified remains of three species of birds and two species of mammals in the six pellets. If all pellets are treated as a single sample, the minimum catch of the owl would include: a Ring-necked Pheasant, an American Robin, Turdus migratorius Linné, 1766; a Northern Cardinal, Cardinalis cardinalis Linné, 1758; two eastern cottontail rabbits, Sylvilagus floridanus (J.A. Allen, 1890); and three meadow voles, Microtus pennsylvanicus (Ord, 1815). Treating pellets as individual samples increases the catch to a pheasant, two robins, two cardinals, four rabbits, and three voles. All of these species have been reported previously as prey items of the Great Horned Owl in Pennsylvania (Wink et al. 1987). In this examination, however, only the mammals were represented by osteological remains. One bird, a Northern Cardinal, was represented by the ramphotheca from a lower mandible as well as by small body feathers. A second species, an American Robin, was represented only by small body feathers. Two of the three species of avian prey would not have been identified without the use of feather identification techniques.

Previous studies indicate that Great Horned Owls typically cast a single pellet per meal, although individuals will occasionally cast two (Dodson and Wexlar 1979; Duke et al. 1975, 1976; Fuller and Duke 1979; Marti 1973), and remains of a single prey can end up in multiple pellets (Lowe 1980). Hence, one would have expected to find bird bones in at least one of the six pellets that we studied. Two factors may account for the lack of bird bones in these pellets. First, the owl may not have ingested all of the bones of some of its prey. In feeding on birds, Great Horned Owls often remove the flesh from the bones, sometimes leaving behind entire articulated skeletons (Einarsen 1956) or only partially eaten

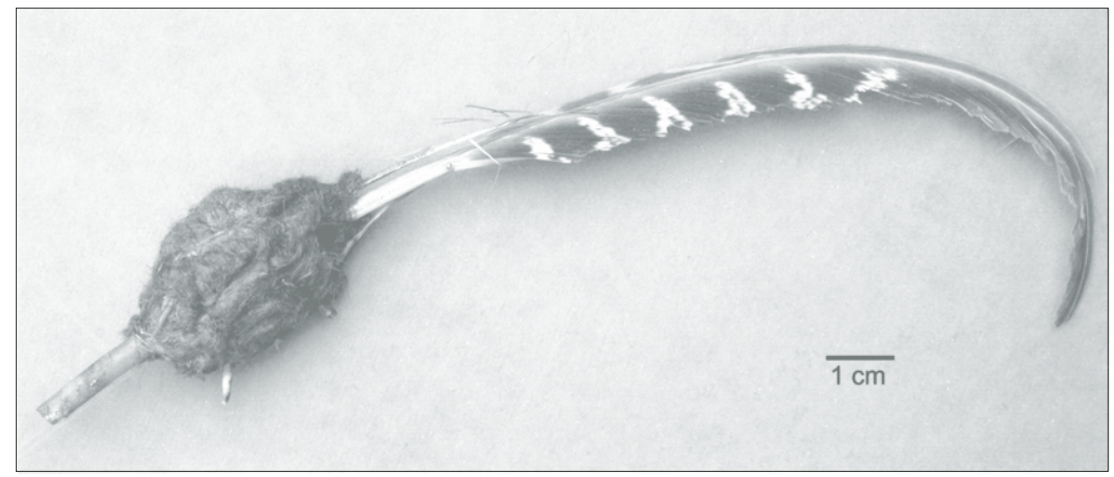

Figure 1. Pellet from Great Horned Owl, containing a nearly entire right Primary-9 from an adult male Ring-necked Pheasant, recovered near Blue Marsh Lake, PA. 
carcasses (Bosakowski et al. 1989). They may also remove heads, wings, and other parts of larger prey (along with diagnostic bones and larger feathers) prior to ingestion (Bosakowski et al. 1989, Hayward et al. 1993). Second, the owl may have chemically digested some of the ingested bones. In general, larger species of owls tend to produce pellets with lower proportions of bones. Great Horned Owls, in particular, show a propensity to crush the bones of their prey prior to ingestion, making them more susceptible to chemical dissolution (Dodson and Wexlar 1979, Duke et al. 1976). Dodson and Wexlar (1979) reported nearly 50\% bone loss of small mammals between ingestion of whole prey and egestion of pellets by Great Horned Owls, and subsequent counts of prey items from pellets yielded an $18 \%$ underestimate of individual prey. Similarly, Raczynski and Ruprecht (1974) showed 8-21\% underrepresentation of individual mammalian prey in pellets of three species of European owls. Bone survivorship can vary by season, among species and age groups of owls, and among species and age groups of their prey (Lowe 1980, Raczynski and Ruprecht 1974). The amounts of both breakage and dissolution are greater, for example, in juvenile owls (Andrews 1990), resulting in greater bone loss than in pellets from adult owls (Raczynski and Ruprecht 1974). Longer retention times of remains in the stomach also appears to greatly decrease the number of bones that appear in egested pellets (Errington 1930). Because bird bones tend to be thinner and lighter than those of mammals, they may be more susceptible to chemical digestion (Duke et al. 1973) and therefore less likely to be present in egested pellets. Although some experimental investigations have included both birds and mammals in the laboratory diets of owls (e.g., Duke et al. 1973, Errington 1930, Lowe 1980, Raczynski and Ruprecht 1974), most have not (e.g., Dodson and Wexlar 1979, Duke and Rhoades 1977, Duke et al. 1976, Fuller and Duke 1979, Marti 1973). Although Errington (1930) quantified the representation of bird bones in pellets, his samples were too small to draw conclusions, except to say that neither small birds nor mice were always represented in pellets in equal numbers to those that were ingested. These two factors, non-ingestion and digestion of bone, are not mutually exclusive, and both probably play an important role in limiting the numbers of bird bones recovered from the pellets of Great Horned Owls.

Mammals have been reported to constitute the majority of prey of Great Horned Owls in North America, averaging 78\% of individual prey items (Snyder and Wiley 1976) and 90\% of calculated biomass (Houston et al. 1998). Birds represent the next largest group of vertebrate prey, averaging $6 \%$ of individual prey, or nearly $9 \%$ of biomass. One of the primary means of determining the feeding habits of owls is the identification of prey remains from egested pellets (Houston et al. 1998). Some studies specifically include feathers among the remains used to identify prey (Cromrich et al. 2002, 
Errington 1930, Schemnitz and Ables 1962), however, it is common for investigators to use only osteological remains (e.g., Aigner et al. 1994, Dexter 1978, Hayward et al. 1993, Llinas-Gutiérrez et al. 1991, Parmalee 1954, Zimmerman et al. 1996), or to not specify what remains were used to identify prey (e.g., Marti and Kochert 1996, Wink et al. 1987). Lack of bones of consumed birds in pellets can result in underestimates of the contribution of avian species to an owl's diet, as well as in calculations of overall intake of biomass and energy. In our analysis of just six pellets, three species of birds, representing at least three of eight identifiable prey items, were not represented by bony elements.

This observation draws attention to a potentially significant bias in investigations that use only osteological remains to determine the diets and prey of pellet-producing raptors, and it underscores the importance of using feather and hair identifications in studies of prey remains (Day 1966, Ellis et al. 2002, Gilbert and Nancekivell 1982, Ward and Laybourne 1985). Moreover, it indicates the importance of stating explicitly the methodologies and evidence on which dietary analyses of raptors are based.

\section{Acknowledgments}

This study resulted from cooperative efforts of the USGS Biological Survey Unit and the Department of Zoology, National Museum of Natural History. Jeremy Jacobs and Sandra Raredon assisted with digital x-ray analyses.

\section{Literature Cited}

Aigner, P.A., M.L. Morrison, L.S. Hall, and W.M. Block. 1994. Great Horned Owl food habits at Mono Lake, California. Southwestern Naturalist 39:286-288.

Andrews, P. 1990. Owls, Caves, and Fossils. British Museum (Natural History), London, UK.

Bosakowski, T., R. Speiser, and D.G. Smith. 1989. Nesting ecology of forestdwelling Great Horned Owls, Bubo virginianus, in the eastern deciduous forest biome. Canadian Field-Naturalist 103:65-69.

Cromrich, L.A., D.W. Holt, and S.M. Leasure. 2002. Trophic niche of North American Great Horned Owls. Journal of Raptor Research 36:58-65.

Day, M.G. 1966. Identification of hair and feather remains in the gut and faeces of stoats and weasels. Journal of Zoology 148:201-217.

Dexter, R.W. 1978. Mammals utilized as food by owls in reference to the local fauna of northeastern Ohio. Kirtlandia 24:1-6.

Dodson, P., and D. Wexlar. 1979. Taphonomic investigations of owl pellets. Paleobiology 5:275-284.

Duke, G.E., and D.D. Rhoades. 1977. Factors affecting meal to pellet intervals in Great-horned Owls. Comparative Biochemistry and Physiology 56A:283-286.

Duke, G.E., J.G. Ciganek, and O.A. Evanson. 1973. Food consumption and energy, water, and nitrogen budgets in captive Great-Horned Olws (Bubo virginianus). Comparative Biochemistry and Physiology 44A:283-292. 
Duke, G.E., A. Jegers, G. Loff, and O.A. Evanson. 1975. Gastric digestion in some raptors. Comparative Biochemistry and Physiology 50A:649-656.

Duke, G.E., O.A. Evanson, and A. Jegers. 1976. Meal to pellet intervals in 14 species of captive raptors. Comparative Biochemistry and Physiology 53A:1-6.

Ellis, D.H., B.A. Sabo, J.K. Fackler, and B.A. Millsap. 2002. Prey of the Peregrine Falcon (Falco peregrinus cassini) in southern Argentina and Chile. Journal of Raptor Research 36:315-319.

Einarsen, A.S. 1956. Determination of some predator species by field signs. Oregon State Monographs, Studies in Zoology 10:1-34.

Errington, P.L. 1930. The pellet analysis method of raptor food habits study. Condor 32:292-296.

Fuller, M.R., and G.E. Duke. 1979. Regulation of pellet egestion: The effects of multiple feedings on meal to pellet intervals in Great Horned Owls. Comparative Biochemistry and Physiology 62A:439-444.

Gilbert, F.F., and E.G. Nancekivell. 1982. Food habits of mink (Mustela vison) and otter (Lutra canadensis) in northern Alberta. Canadian Journal of Zoology 60:1282-1288.

Hayward, J.L., J.G. Galusha, and G. Frias. 1993. Analysis of Great Horned Owl pellets with Rhinoceros Auklet remains. Auk 110:133-135.

Houston, C.S., D.G. Smith, and C. Rohner. 1998. Bubo virginianus. Great Horned Owl. In A. Poole and F. Gill (Eds.). The Birds of North America, No. 372. The Birds of North America, Inc., Philadelphia, PA.

Llinas-Gutiérrez, J., G. Arnaud, and M. Acevedo. 1991. Food habits of the Great Horned Owl (Bubo virginianus) in the Cape Region of Lower California, Mexico. Journal of Raptor Research 25:140-141.

Lowe, V.P.W. 1980. Variation in digestion of prey by the Tawny Owl (Strix aluco). Journal of Zoology 192:283-293.

Marti, C.D. 1973. Food consumption and pellet formation rates in four owl species. Wilson Bulletin 85:178-181.

Marti, C.D., and M.N. Kochert. 1996. Diet and trophic characteristics of Great Horned Owls in southwestern Idaho. Journal of Field Ornithology 67:499-506.

Parmalee, P.W. 1954. Food of the Great Horned Owl and Barn Owl in east Texas. Auk 71:469-470.

Raczynski, J., and A.L. Ruprecht. 1974. The effect of digestion on the osteological composition of owl pellets. Acta Ornithologica 14:25-38.

Sabo, B.A., and R.C. Laybourne. 1994. Preparation of avian material recovered from pellets and as prey remains. Journal of Raptor Research 28(3):192-193.

Schemnitz, S.D., and E. Ables. 1962. Notes on the food habits of the Great Horned Owl in western Oklahoma. Condor 64:328-329.

Snyder, N.F.R., and J.W. Wiley. 1976. Sexual size dimorphism in hawks and owls of North America. Ornithological Monographs 20:i-vi, 1-95.

Ward, F.P., and R.C. Laybourne. 1985. A difference in prey selection by adult and immature peregrine falcons during autumn migration. Pp. 303-309, In I. Newton and R.D. Chancellor (Eds.). Conservation Studies on Raptors. International Conservation of Bird Preservation Technical Publication 5. 
Wink, J., S.E. Senner, and L.J. Goodrich. 1987. Food habits of Great Horned Owls in Pennsylvania. Proceedings of the Pennsylvania Academy of Science 61:133-137.

Zimmerman, G., P. Stapp, and B. Van Horne. 1996. Seasonal variation in the diet of Great Horned Owls (Bubo virginianus) on shortgrass prairie. American Midland Naturalist 136:149-156. 